\title{
Tritium Transport Vessel Using Depleted Uranium (U)
}

by

$$
\text { Conf-950506--11 }
$$

L. K. Heung

Westinghouse Savannah River Company

Savannah River Site

Aiken, South Carolina 29808

A document prepared for FIFTH TOPICAL METTING ON TRITIUM TECHNOLOGY IN FISSION, FUSION AND ISOTOPIC APPLICATIONS at Belgirate, Lake Maggiore from 05/28/95 - 06/03/95.

DOE Contract No. DE-AC09-89SR18035

This paper was prepared in connection with work done under the above contract number with the U.S.

Department of Energy. By acceptance of this paper, the publisher and/or recipient acknowledges the U. S. Government's right to retain a nonexclusive, royalty-free license in and to any copyright covering this paper, along with the right to reproduce and to authorize others to reproduce all or part of the copyrighted paper. 


\section{DISCLAIMER}

This report was prepared as an account of work sponsored by an agency of the United States Government. Neither the United States Government nor any agency thereof, nor any of their employees, makes any warranty, express or implied, or assumes any legal liability or responsibility for the accuracy, completeness, or usefulness of any information, apparatus, product, or process disclosed, or represents that its use would not infringe privately owned rights. Reference herein to any specific commercial product, process, or service by trade name, trademark, manufacturer, or otherwise does not necessarily constitute or imply its endorsement, recommendation, or favoring by the United States Government or any agency thereof. The views and opinions of authors expressed herein do not necessarily state or reflect those of the United States Government or any agency thereof.

This report has been reproduced directly from the best available copy.

Available to DOE and DOE contractors from the Office of Scientific and Technical Information, P.O. Box 62, Oak Ridge, TN 37831; prices available from (615) 576-8401.

Available to the public from the National Technical Information Service, U.S. Department of Commerce, 5285 Port Royal Road, Springfield, VA 22161. 


\section{DISCLAIMER}

Portions of this document may be illegible in electronic image products. Images are produced from the best available original document. 


\title{
TRITIUM TRANSPORT VESSEL USING DEPLETED URANIUM
}

\author{
L. K. Heung \\ Westinghouse Savannah River Company \\ 773-A, Savannah River Site, Aiken, SC 29808, USA
}

\begin{abstract}
A tritium transport vessel using depleted uranium was tested in the laboratory using deuterium and protium. The vessel contains $0.5 \mathrm{~kg}$ of depleted uranium and can hold up to 18 grams of tritium. The conditions for activation, tritium loading and tritium unloading were defined. The safety aspects that included airingress, tritium diffusion, temperature and pressure potentials were evaluated.
\end{abstract}

\section{INTRODUCTION}

Tritium can be transported in a gas tank or in a metal hydride bed. A gas tank is relatively large and the gas can escape easily if a leak develops. A metal hydride bed stores the tritium as a solid which occupies a small volume and can not escape as a gas does. It is therefore advantageous to transport tritium in a metal hydride bed. Many metals and alloys can react with tritium gas to form a solid metal tritide and are candidates for use in tritium transport. The tritium gas can be recovered from the solid by heat or by exchange with its isotopes, deuterium or protium.

Existing tritium transport containers include gas tanks with capacities up to 12 grams, and uranium beds with capacities up to 5 grams. ${ }^{1}$ Their certifications will expire soon. Replacements with improved designs are needed.

In the 4th quarter of 1991, a program to develop a transport vessel using depleted uranium, with capacity for up to 18 gram of tritium was initiated at the Savannah River Site. An experimental transport vessel was fabricated and tested in the laboratory, before the final design was completed. This report summarizes the tests results.

\section{THE TRANSPORT VESSEL}

The experimental vessel is shown in Figure 1. The body of the vessel is a machined cup of stainless steel $316 \mathrm{~L}$ covered by a welded-on top. The inside diameter is $9.2 \mathrm{~cm}$ ( 3.62 inch) and the high is $5.72 \mathrm{~cm}$ ( $2.25 \mathrm{inch})$. The thickness is $0.48 \mathrm{~cm}(0.19 \mathrm{inch})$ at the side, $0.99 \mathrm{~cm}(0.39 \mathrm{inch})$ at the top and $0.66(0.26 \mathrm{inch})$ at the bottom. The container volume is $379 \mathrm{cc}$ (23.15 in 3$)$. 
Two $0.95 \mathrm{~cm}(3 / 8 \mathrm{inch})$ tube are welded on the top plate as inlet/outlet ports. A 5 -micron, cup shaped, porous stainless filter is welded on the end of each tube to confine the uranium powders inside the vessel. One filter is positioned above the uranium powder, while the other is in the powder. The one in the powder is used when a flow-through mode of operation is desired. The valves at the inlet/outlet ports are all metal and welded bellows sealed.

Depleted uranium $(492.5 \mathrm{~g})$ in pieces of about $1.27 \mathrm{~cm}$ dimensions was placed in the vessel before the top plate was welded on. A typical analysis of the depleted uranium is $\mathrm{U}-235=0.200 \mathrm{wt} \%, \mathrm{U}-236=0.004 \mathrm{wt} \%$ and $\mathrm{U}-238=99.796 \mathrm{wt} \%$. The densities of loosely and tightly packed uranium hydride powders are about 4 and $6.6 \mathrm{~g} / \mathrm{cc}$, respectively. The space occupied by the uranium hydride bulk will be about $123 \mathrm{cc}$, compared with the total volume of the vessel of $379 \mathrm{cc}$.

The final design of the vessel is shown in Figure 2. It has the same basic components as the experimental unit, except some improved features. The vessel body is formed by welding two pipe caps together to increase the strength to weight ratio. Stainless steel type $374 \mathrm{H}$ is used to avoid the need of heat treatment after welding. The tubing lengths from the top of the vessel to the inlet/outlet valves are increased to lower the valve temperature during heating. The tubings are folded so that the overall dimension is still small. The porous stainless steel filters are 2 micron nominal pore size to improve the confinement of fines.

\section{THE TEST APPARATUS}

The test apparatus is illustrated in Figure 3. A gas manifold, equipped with pressure transducers, supplies of protium, and calibrated volumes, was used for the tests. An open top electric furnace (National Element, Inc. model FD-104), with a 5-inch diameter, 5 inch deep cavity was used to heat the vessel. The vessel was installed in this cavity with its top flush with the top of the furnace. During heating the top was covered with ceramic insulation material to preserve heat and to protect the valves from high temperatures. The furnace temperature was controlled by using a temperature controller. An IBM PC with a Keithley 500 data acquisition system are used to record the temperatures and pressures.

\section{PROPERTIES OF THE URANIUM-HYDROGEN SYSTEM}

Many studies have been conducted on the uranium-hydrogen (including $H, D$, and T) system.2,3 The thermodynamic properties taken from references 2 and 3 are summarized in Table 1, which can be used to calculate the equilibrium pressures at different temperatures for the isotopes. When uranium is saturated with tritium to form $\mathrm{UT}_{3}$, it can retain the decay helium in the solid for about 300 days to reach a helium concentration of about $0.136 \mathrm{He} / \mathrm{U}$. After that part of the decay helium starts to release. The release rate increases gradually over a period 
of about 600 days, before it becomes the same as the gereration rate. ${ }^{4}$ The vessel must be designed to contain the expected pressure of helium.

\section{ACTIVATION}

Depleted uranium metal usually does not react with hydrogen at room temperature, because its surface is covered with a protective layer of oxide. But it can be activated by heating to high temperature under hydrogen atmosphere. The activation cracks the oxide layer and breaks the metal into small particles. The uranium in the vessel was activated using the following steps:

1. Heat the vessel to $450{ }^{\circ} \mathrm{C}$ under vacuum for two hours to remove volatile impurities.

2. Expose the uranium to about 2500 torr hydrogen pressure while the temperature is increased to about $200^{\circ} \mathrm{C}$, until the uranium is saturated with hydrogen, which takes about 3 hours.

3. Heat the uranium hydride to $450{ }^{\circ} \mathrm{C}$ under vacuum until desorption of the hydrogen is complete, which requires about 5 hour.

The hydrogen pressure, temperature and hydrogen in the uranium as a function of time during activation of the experimental vessel are shown in Figure 4 . The uranium was heated to $450^{\circ} \mathrm{C}$ under vacuum for about 2 hours, then cooled down to room temperature, before it was exposed to 2,200 torr of hydrogen from a 40 liter volume. When the vessel is at room temperature, there was little absorption for more than one hour. The heat was turned on and when the temperature reached about $100^{\circ} \mathrm{C}$, the absorption rate began to increase. After about 2 hours at about $200^{\circ} \mathrm{C}$, the hydrogen concentration reached about $2.8 \mathrm{H} / \mathrm{U}$ (hydrogen to uranium atom ratio), compared with a theoretical maximum of 3.0. The saturated uranium was then heated to $450^{\circ} \mathrm{C}$ under evacuation to desorb the hydrogen. When there was no more gas at less than 0.5 torr pressure the desorption is considered complete, and the uranium is activated.

\section{ABSORPTION (LOADING HYDROGEN)}

Loading hydrogen to the vessel is done simply by feeding the hydrogen to the vessel at room temperature (ambient cooling). A typical set of pressure, temperature and saturation data is shown in Figure 5. When the uranium was exposed to the 1500 torr hydrogen, the absorption was very fast, as indicated by the rapid decrease of pressure, increases of temperature and hydrogen content $(\mathrm{H} / \mathrm{U})$. After the temperature had peaked at about $170^{\circ} \mathrm{C}$, the absorption became controlled by the slow dissipation of heat from the vessel. It took about one hour to saturate the uranium under the conditions tested. 
The maximum temperature which the uranium can reach during hydrogen absorption is dependent on the hydrogen gas pressure. This temperature may be calculated with the equilibrium equation given in Table 1. For example, a deuterium pressure of 4070 torr, or a tritium pressure of 5390 torr, can generate a temperature of $500{ }^{\circ} \mathrm{C}$. Pressures higher than these values should be avoided when loading hydrogen to the vessel, to avoid overheating the uranium. Uranium and iron are known to form an eutectic compound at $725^{\circ} \mathrm{C}$ that can damage the vessel.

When the feed gas contains significant levels of inerts, the loading may be done in a flow-through mode to avoid the inert blanketing problem. To test the effectiveness of the flow-through operation, feeds containing helium, at 1600 torr, were expanded from the 40-liter volume, through the vessel, to the 2.5-liter volume. The results showed that with $1 \%$ and $10 \%$ helium in the feed, $98 \%$ and $89 \%$ of the hydrogen were removed, indicating that the flow-through mode is an effective way to load feeds containing inerts.

\section{DESORPTION (UNLOADING)}

Desorption (unloading) was accomplished by heating the vessel to about $450^{\circ} \mathrm{C}$ under evacuation. A typical set of desorption data is shown in Figure 6. The rate of desorption was indicated by the pressure in the vessel. When the temperature reached about $350^{\circ} \mathrm{C}$, the desorption rate became significant and the pressure began to increase until it reached a maximum of about 20 torr. After about 3.5 hours at $450^{\circ} \mathrm{C}$, the pressure dropped rapidly to zero, indicating the desorption was complete. The higher is the temperature, the quicker is the desorption. Tests showed that the desorption time could be shortened from 5.5 hours to 4 hours when the temperature was increased from 450 to $500^{\circ} \mathrm{C}$.

\section{AIR INGRESS TESTS}

Air ingress effect on uranium beds has been studied before using a variety of conditions. ${ }^{6}$ In this work additional tests were conducted under two different states: first as uranium hydride $\left(\mathrm{UH}_{3}\right)$ then as desorbed uranium $(\mathrm{U})$.

In the first test, the vessel was saturated with hydrogen at room temperature under about 500 torr hydrogen pressure. The over pressure was evacuated for 5 minutes. Since the hydrogen pressure over $\mathrm{UH}_{3}$ at room temperature is only about 2E-6 torr, the brief evacuation could not remove any significant amount of hydrogen from the uranium hydride. The vessel was then opened to ambient air through a valve. The pressure in the vessel and temperature on the outside wall of the vessel were recorded. The results are shown in Figure 7. The pressure quickly jumped to atmospheric pressure, and the temperature stayed at room 
temperature, indicating little or no reaction between air and the uranium hydride $\left(\mathrm{UH}_{3}\right)$ powder in the vessel.

After the air exposure, the vessel was heated to $400{ }^{\circ} \mathrm{C}$ under evacuation for 8 hours to desorb the hydrogen. After that, the ability of the uranium to absorb hydrogen was tested. The test showed that the uranium absorbed the hydrogen immediately, but the capacity had decreased to $2.5 \mathrm{H} / \mathrm{U}$, a $10 \%$ decrease compared with the original capacity of $2.8 \mathrm{H} / \mathrm{U}$. The small decrease in capacity is likely due to the formation of some uranium oxide, though too small to be detected by the pressure and temperature measurements during the air ingress test.

In the second test, the uranium hydride was completely desorbed at $450{ }^{\circ} \mathrm{C}$ under vacuum, and cooled to room temperature. The vessel was then opened to ambient air through a valve. The pressure and temperature were recorded the same way as before. The results are shown in Figure 8. Different from the $\mathrm{UH}_{3}$ test, this time the pressure increased very slowly and there was an increase in temperature. The sound of gas rushing through the open valve into the vessel was clearly audible, indicating that the air was consumed rapidly in the vessel. When the air valve was momentarily closed the pressure took an immediate dip to about 250 torr, indicating that both oxygen and nitrogen in the air were consumed. If only oxygen was consumed the pressure would have been 584 torr or higher, since room air contains about $20.7 \%$ oxygen, $76.8 \%$ nitrogen, $1 \%$ argon and $1.5 \%$ moisture. After about 15 minutes, the temperature reached a maximum of about $200{ }^{\circ} \mathrm{C}$, and the reaction slowed down and eventually stopped. This test showed that air ingress into the uranium vessel can only cause a limited increase of temperature; therefore does not create a safety problem. However it is important to point out that letting air into the vessel is different from drawing air through the vessel continuously. when air is continuously drawn through the vessel the results are more serious. That will be discussed in a later section.

After this second air ingress test, the vessel was evacuated at $450^{\circ} \mathrm{C}$ for about 5 hours, before it was exposed to hydrogen at 1600 torr for an absorption test. The results are shown in Figure 9 There was a long delay of about 2 hours before the absorption rate increased sharply. Saturation was reached in one additional hour. The $\mathrm{H} / \mathrm{U}$ at saturation was only 1.7 , a decrease of $32 \%$ compared with $2.5 \mathrm{H} / \mathrm{U}$ after the first air ingress.

The $32 \%$ decrease in capacity is equivalent to a loss of $0.62 \mathrm{~g}$-mole of uranium. The room air contains about $1 \%$ argon and $1.5 \%$ moisture, with the balance being nitrogen and oxygen. If the nitrogen and oxygen all reacted with the uranium, and only argon and moisture were left behind, 14 liters of air would be needed to leave enough argon and moisture to fill the vessel volume to 760 torr. The oxygen and nitrogen in the 14 liters of air would consume about 0.77 mole of uranium if $\mathrm{UO}_{2}$ and $\mathrm{U}_{2} \mathrm{~N}_{3}$ were formed. This $0.77 \mathrm{~g}$-mole is quite close to the 0.62 
g-mole of uranium based on lost absorption capacity. It is therefore reasonable to conclude that argon and moisture accumulation stopped the air from continuing entering the vessel.

\section{AIR FLOW-THROUGH SAFETY}

Oxidation of uranium to form uranium oxide $\left(\mathrm{UO}_{2}\right)$ produces heat of 257 $\mathrm{kcal} /$ mole. With $0.5 \mathrm{~kg}$ of uranium in the vessel, the total heat of oxidation is 539 $\mathrm{kcal}(2139 \mathrm{Btu})$. The heat capacity of the vessel wall plus the uranium is 0.22 $\mathrm{kcal} / \mathrm{C}(0.49 \mathrm{Btu} / \mathrm{F})$. The heat of oxidation can increase the temperature of the vessel by $2450{ }^{\circ} \mathrm{C}$ if there is no heat loss to the ambient. Suppose the heat loss rate is calculated by assuming natural convention $(\mathrm{h}=2 \mathrm{Btu} / \mathrm{hr} / \mathrm{F} / \mathrm{ft} 2)$ from the surface area equal to the opening of the furnace (5" diameter) and a surface temperature of $500^{\circ} \mathrm{C}\left(932{ }^{\circ} \mathrm{F}\right)$. It would be $235 \mathrm{Btu} / \mathrm{hr}\left(2^{*}\left(3.14 / 4^{*} 5^{* 5} / 144\right)^{*} 862\right)$. That will take 4.5 hours to dissipate half of the total heat of oxidation $(2139 / 2 / 235)$. That means there will be still sufficient heat to bring the vessel temperature to well above $1000^{\circ} \mathrm{C}$ for more than 4 hours to oxidize the stainless steel wall. Oxidation of stainless occurs when the temperature is above about 900 ${ }^{\circ} \mathrm{C}$.

The vessel has two ports to permit flow-through loading to avoid accumulation of inert gas. However that will also permit continuous air flow through the vessel if vacuum is on one outlet while an air leak is on the other.

The experimental vessel was severely damaged one weekend when it was left cooling down in the furnace with vacuum on one outlet and a closed valve and a plug on the other. On Monday morning it was found that the vessel top was hot to the touch. The bottom part was blackened, flaked and swollen. The vessel was not leak tight anymore. However, there was no uranium detected outside the vessel. After the damaged vessel was disconnected from the experimental station, it was found that the bottom of the vessel could be pried open with a hand tool. The circumstance indicated that the damage was caused by drawing air through the vessel. The air oxidized the uranium and produced heat to increase the vessel temperature. When the temperature was higher than about $725{ }^{\circ} \mathrm{C}$, the uranium began to react with the iron which produced more heat. When the temperature got above about $900^{\circ} \mathrm{C}$, the vessel began to oxidize which also contributed heat. The analysis earlier had indicated that the vessel could easily reach well above $1000{ }^{\circ} \mathrm{C}$ by oxidation of the uranium alone when air was continuously drawn into the vessel. The formation of uranium oxide, uranium iron and iron oxide could have occurred at the same time, that eventually caused the damage as observed.

The lesson learned from this incident is that the vessel must not be left unattended when it is under evacuation. On the vessel design, while the two-port arrangement permits follow-through operation, it also introduces the possible 
danger of drawing air into the vessel continuously. The balance between operation flexibility and safety should be reconsidered for future vessel designs.

\section{TRITIUM PERMEATION CALCULATION}

The permeation of tritium through the vessel wall under heating and the offgassing rate at room temperature were calculated by using a finite-deference program ${ }^{5}$. The calculated results showed that under the normal desorption condition of $400{ }^{\circ} \mathrm{C}$ and 20 torr tritium pressure, the tritium permeation rate is about $0.08 \mathrm{Ci} / \mathrm{hr}$. After the vessel wall is saturated with tritium at the desorption condition, the offgassing at room temperature is about $5 \mathrm{E}-7 \mathrm{Ci} / \mathrm{hr}$.

\section{SUMMARY AND CONCLUSIONS}

A tritium transport vessel using depleted uranium was fabricated and tested in the laboratory. The tests demonstrated its performance requirements and defined its operation conditions. Air ingress tests showed that uranium hydride did not react with air. But after desorption, the uranium reacted with both oxygen and nitrogen from air. The reaction stopped when the accumulation of argon and moisture reached atmospheric pressure and prevented additional air to go into the vessel. The maximum temperature reached was about $200^{\circ} \mathrm{C}$. If air is drawn through the uranium continuously, a temperature higher than $1,000^{\circ} \mathrm{C}$ can be reached that can cause damage to the vessel.

\section{REFERENCES}

1. R. A. P. Sissingh ahd J. R. Stencel, "Tritium Container Study for Princeton Plasma Physics Laboratory", Report No: DTSD-R-6, January 1988.

2. R. S. Carison, "The Uranium-Tritium System-The Storage Of Tritium", Radiation Effects and Tritium Technology for Fusion Reactors, Oak Ridge National Laboratory, CONF-750989, Vol IV, March 1976.

3. C. J. H. Northrup, Jr., "The Uranium-Hydrogen System", The J of Physical Chemistry, Vol. 79, No. 7, 1975.

4. M. E. Malinowski and P. R. Coronado, "Helium Release From Uranium Tritium", Radiation Effects and Tritium Technology for Fusion Reactors, Oak Ridge National Laboratory, CONF-750989, Vol IV, March 1976.

5. K. E. Kain, "Finite-Diference Program for Hydrogen Diffusion", DP-1738, DuPont Report, March 1987.

6. G. R. Longhurst, A. G. Heics, W. T. Shmayda and R. L. Rossmassler, "Experimental Evaluation of The Consequences of Uranium Bed Air-Ingress Accidents", Fusion Technology, vol 21, p1017, March 1992. 
Table 1 Thermodynamic Properties of Uranium-Hydrogen System

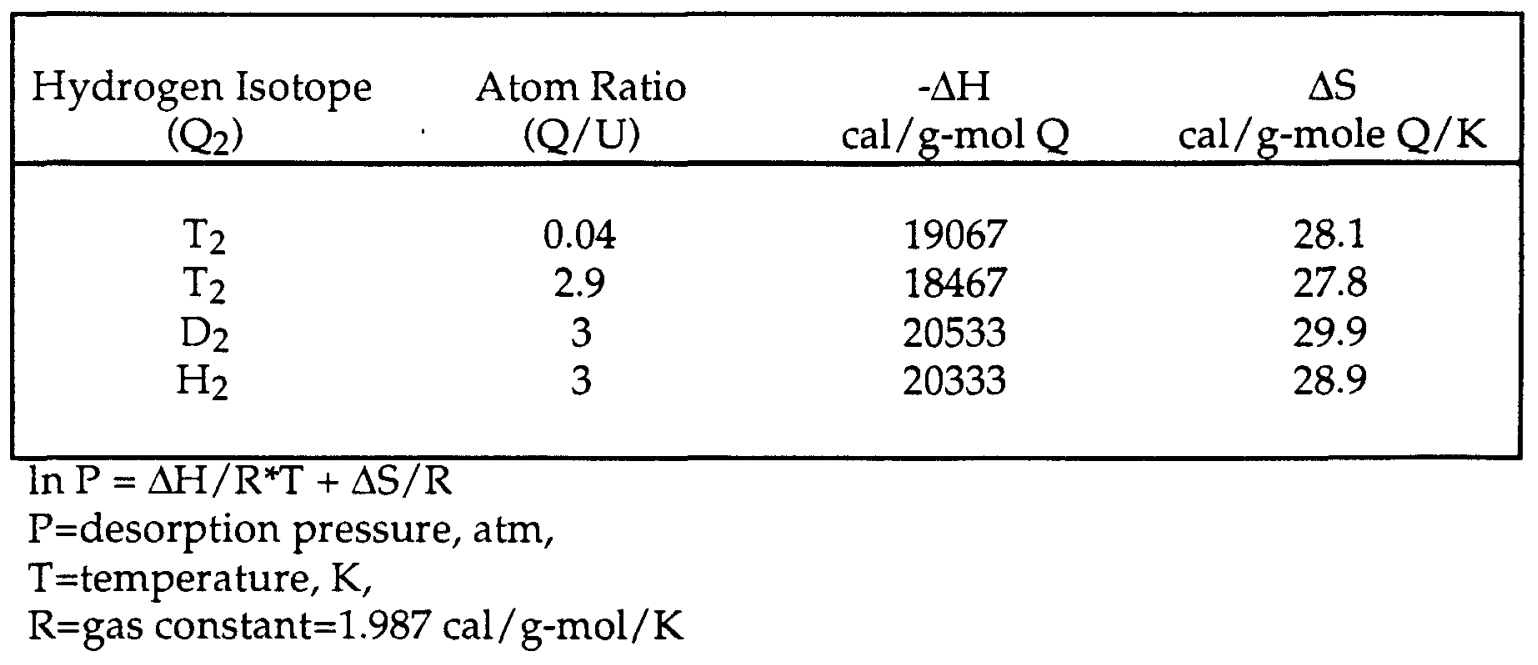


Figure 1 Schematic of Experimental Tritium Transpor Vessel

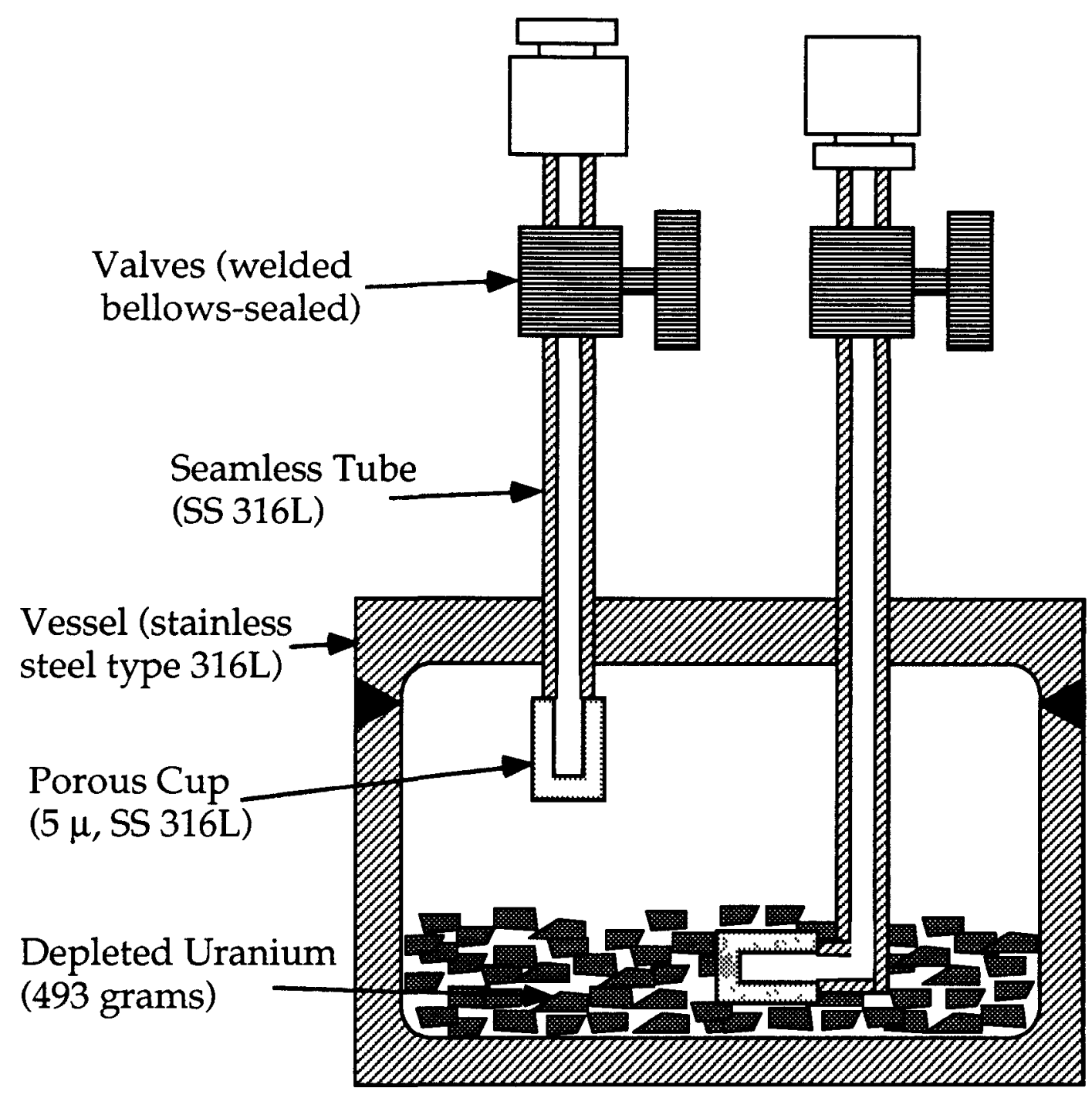


Figure 2 Schematic of Final Design of Tritium Transpor Vessel

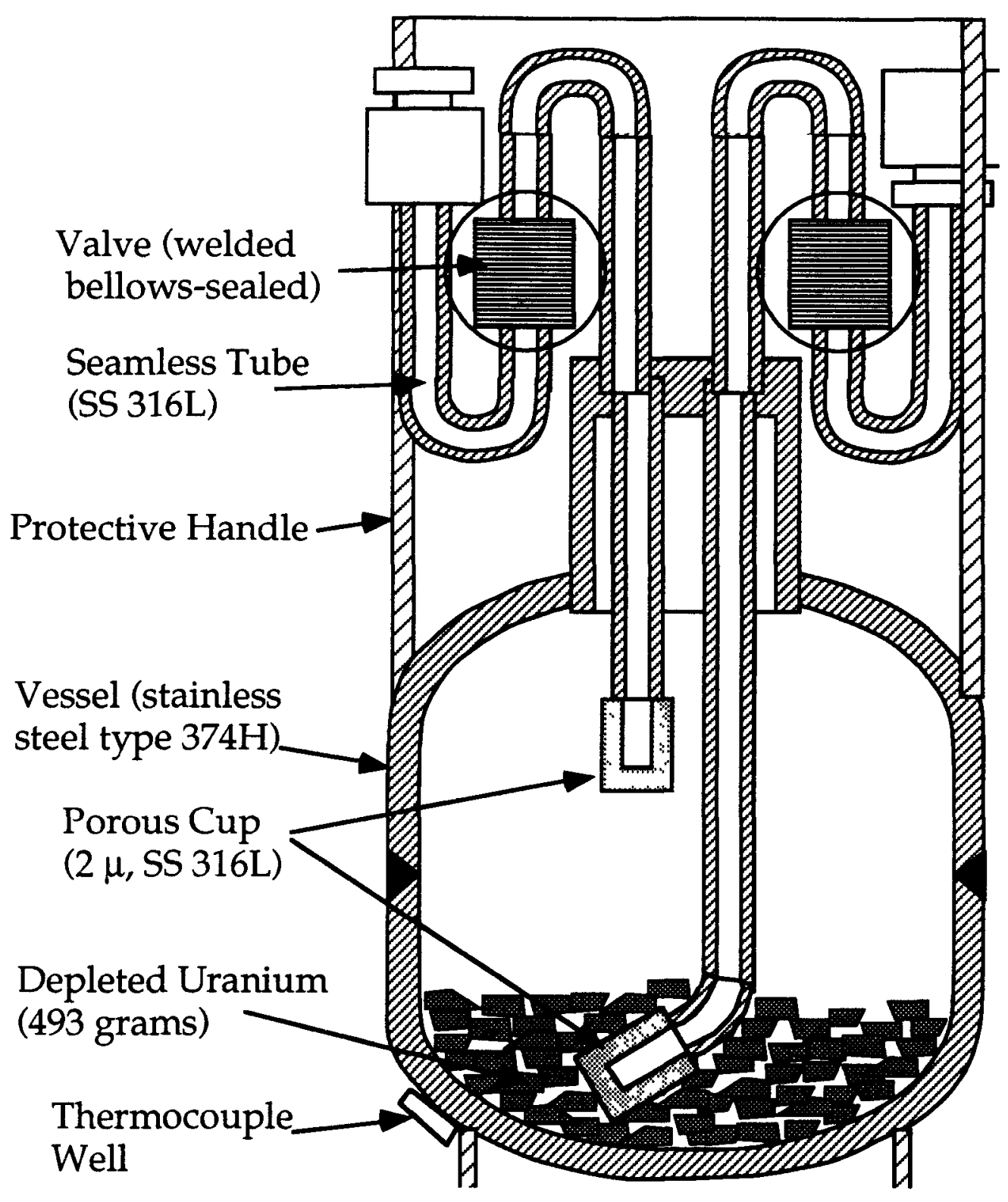


Figure 3 Test Apparatus

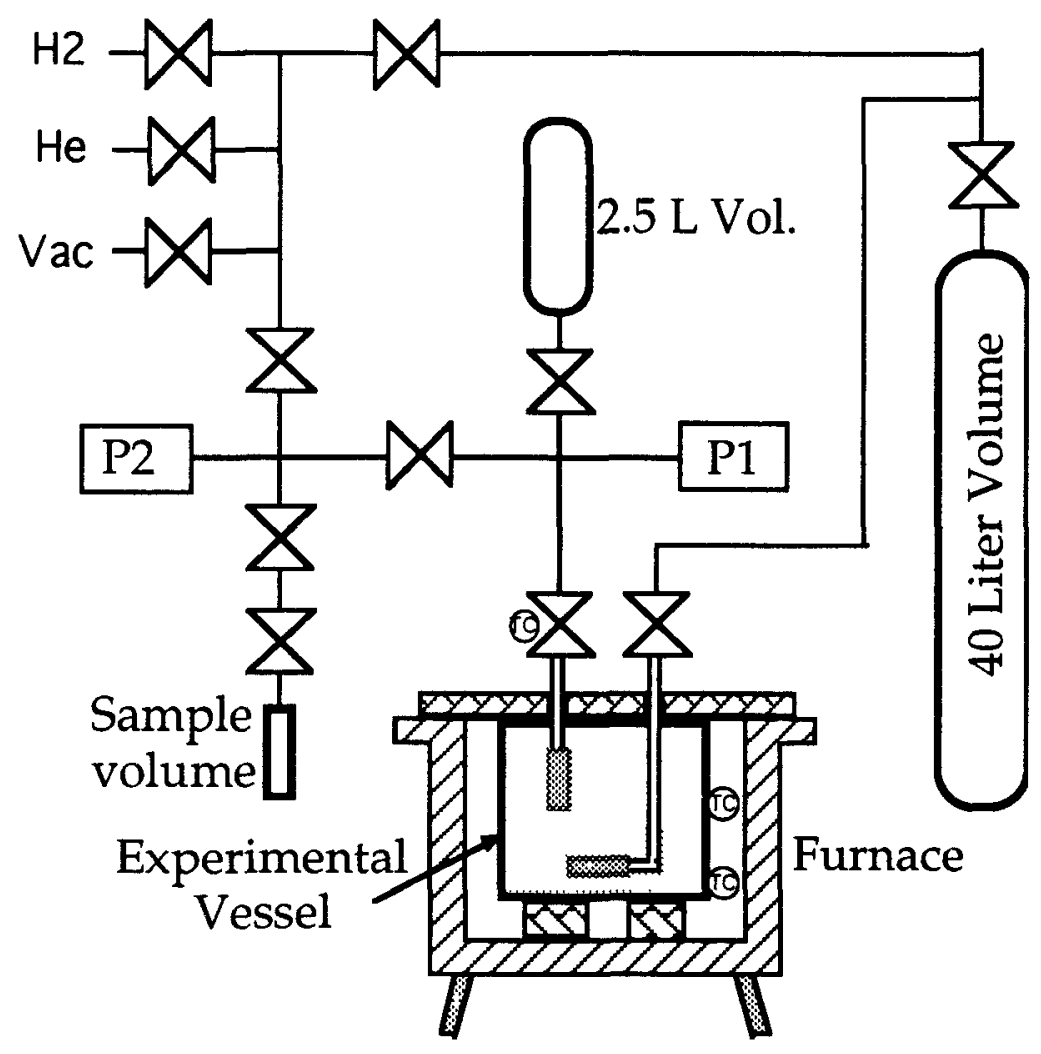


Figure 4 Activation of Uranium Bed

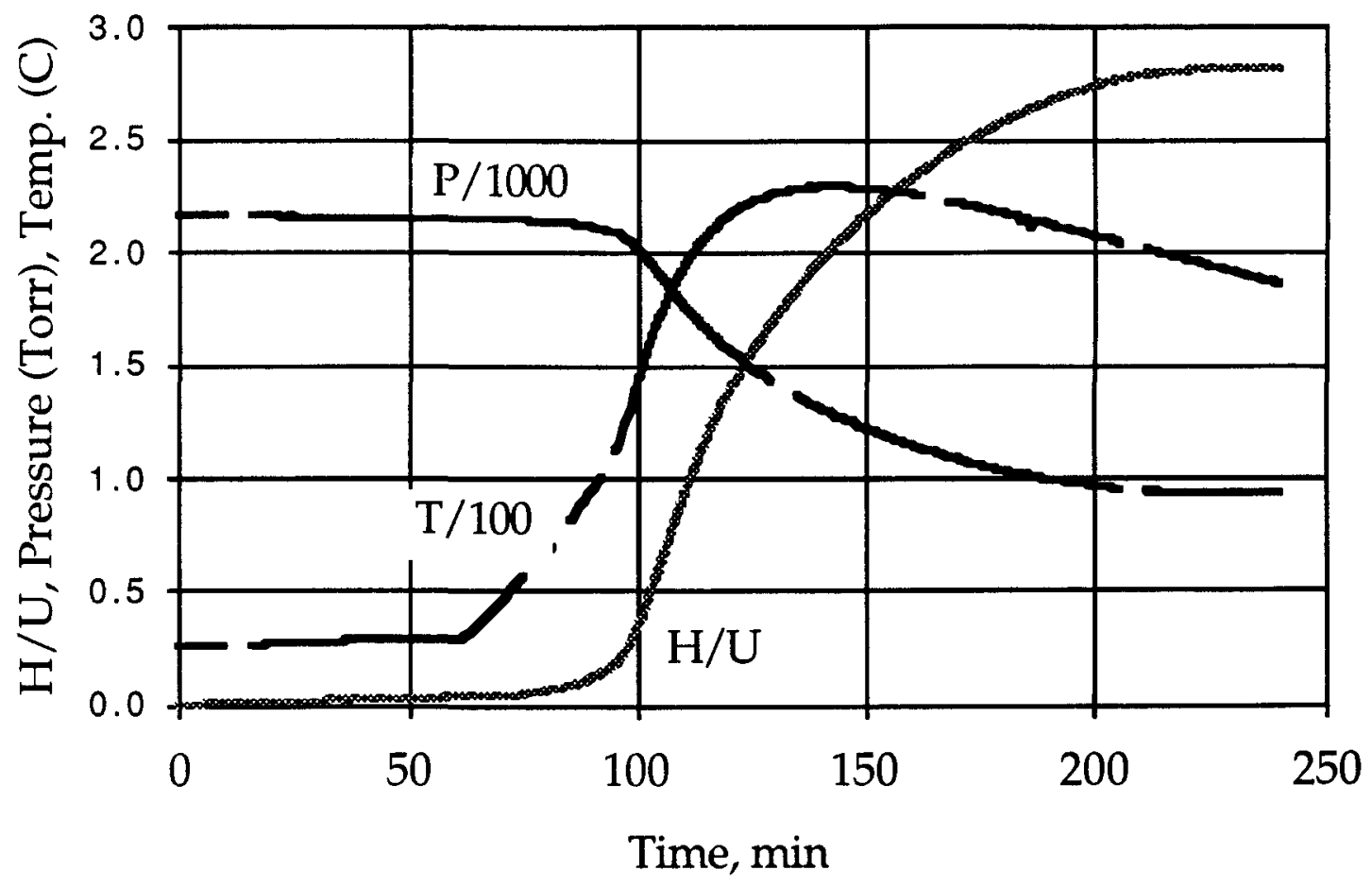


Figure 5 Loading Hydrogen To Uranium Bed

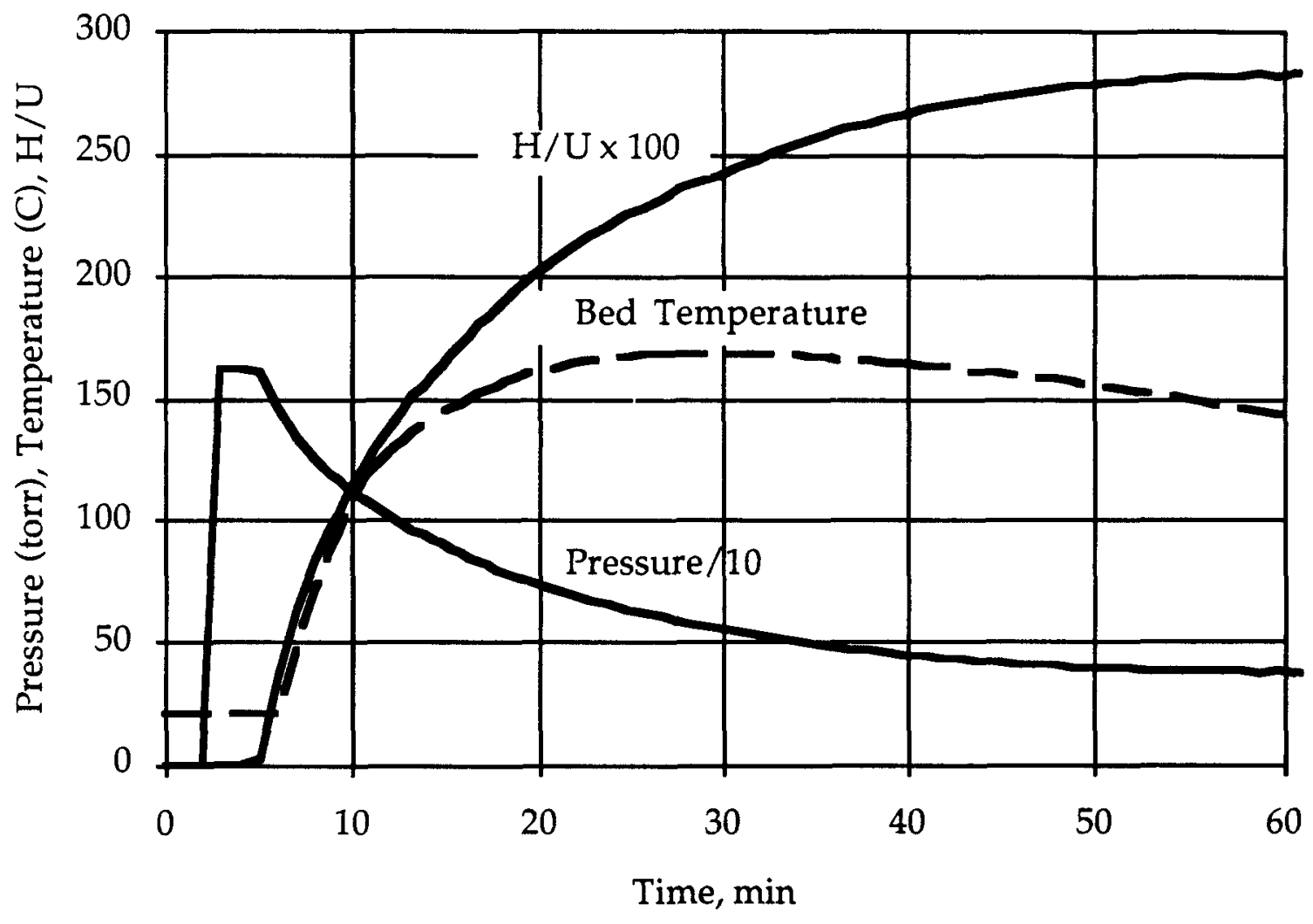


Figure 6 Unloading Hydrogen From Uranium Bed

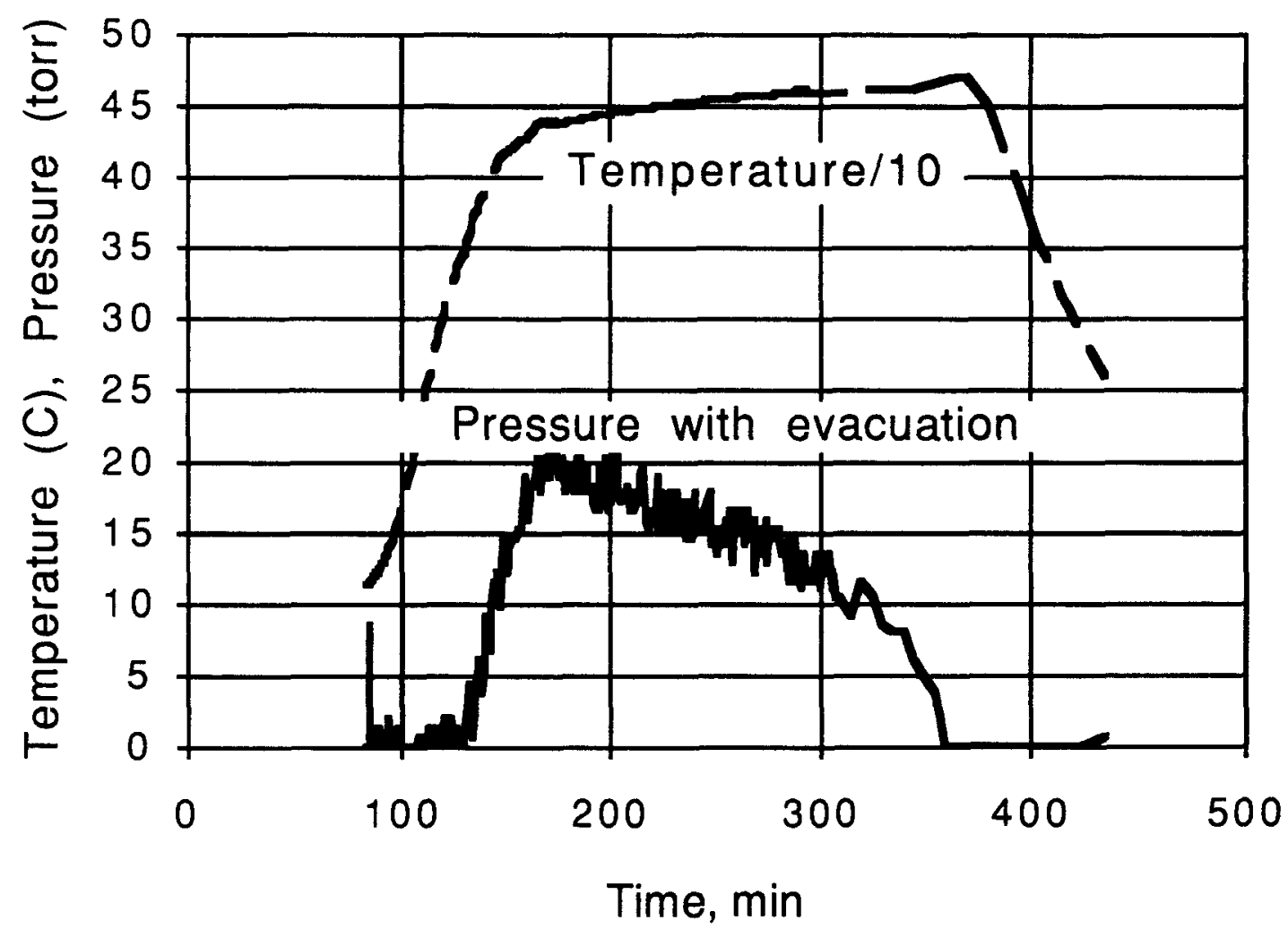


Figure 7 Air Ingress To Uranium Hydride $\left(\mathrm{UH}_{3}\right)$ Bed

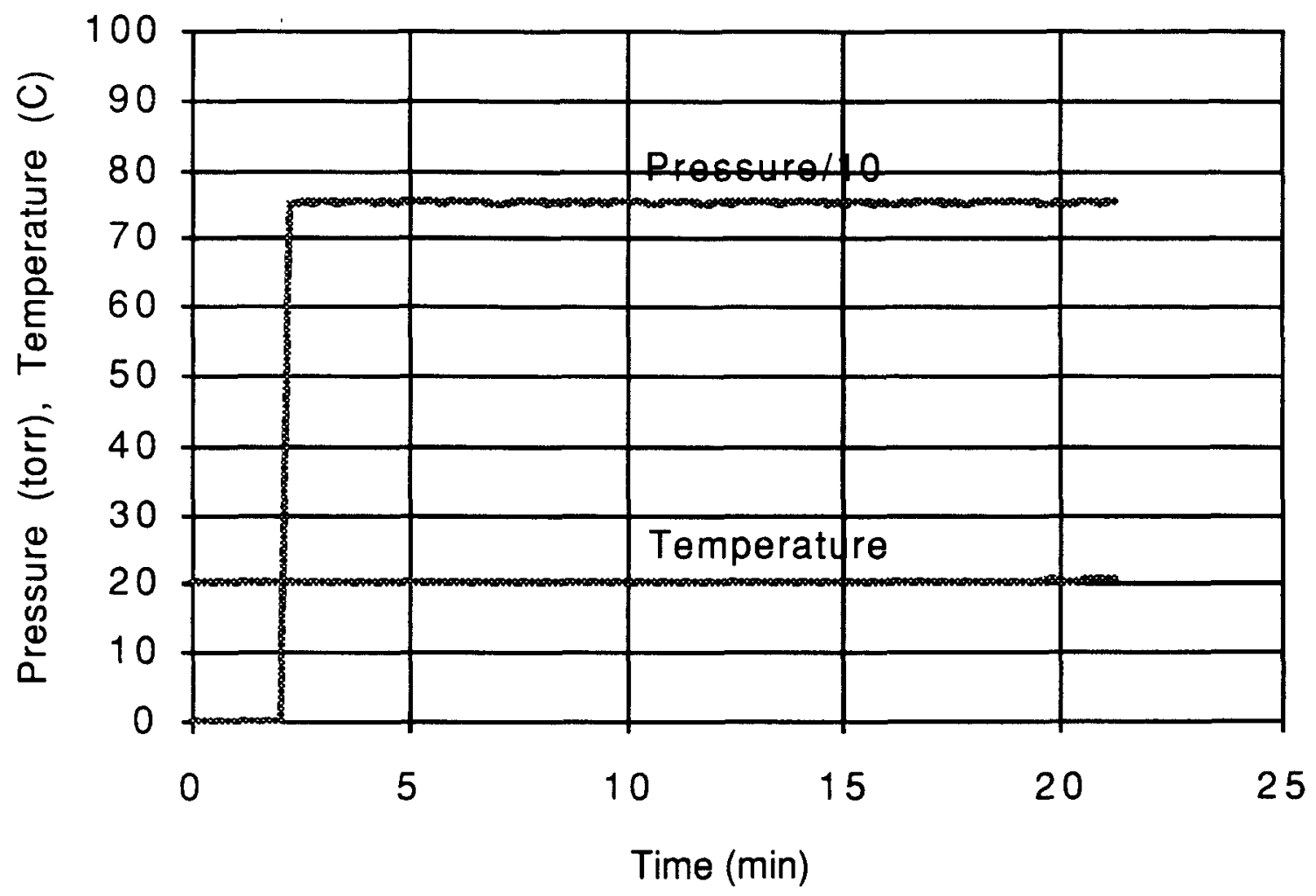


Figure 8 Air Ingress To Uranium (U) Bed

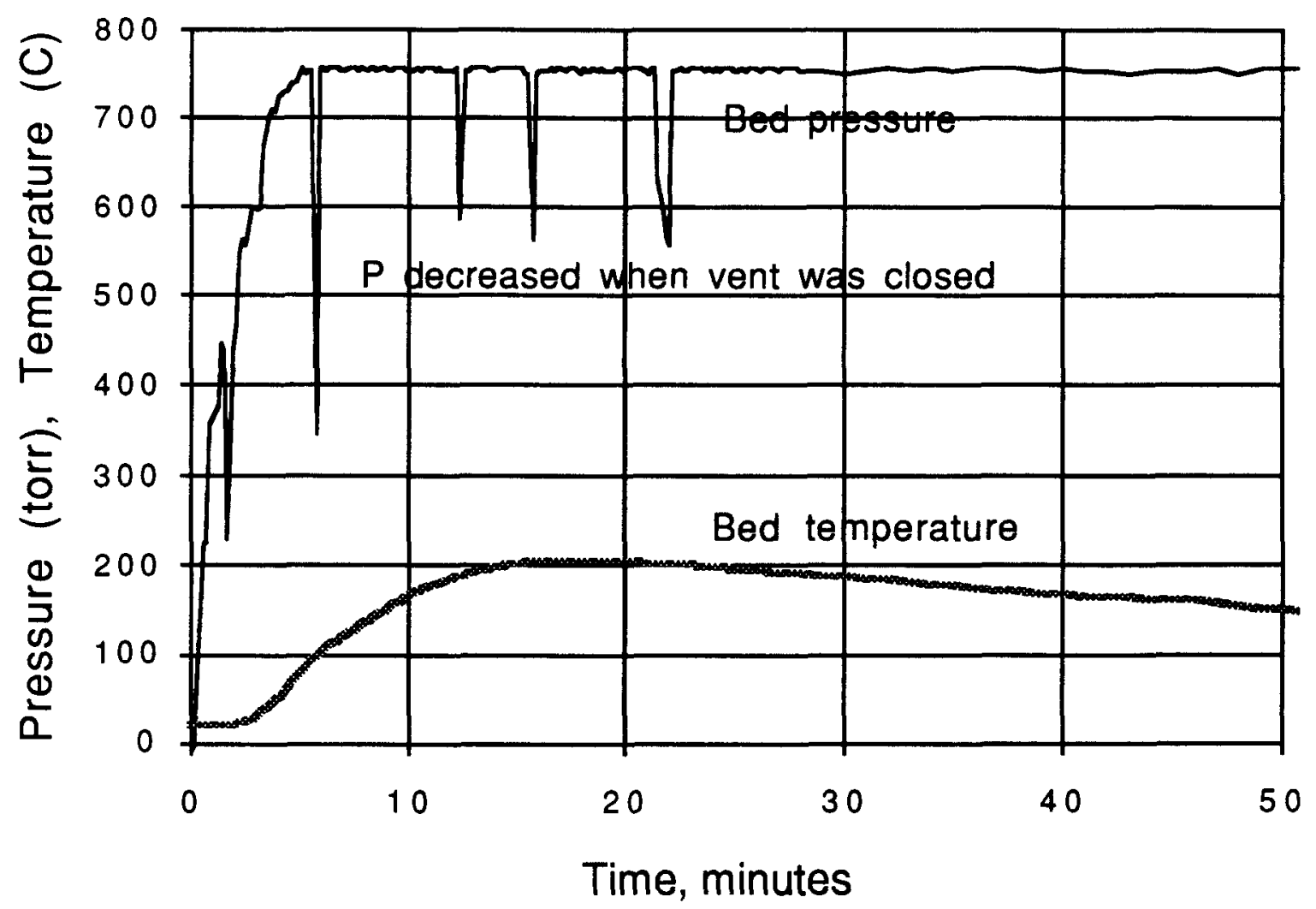


Figure 9 Air Ingress Effect On Uranium Bed

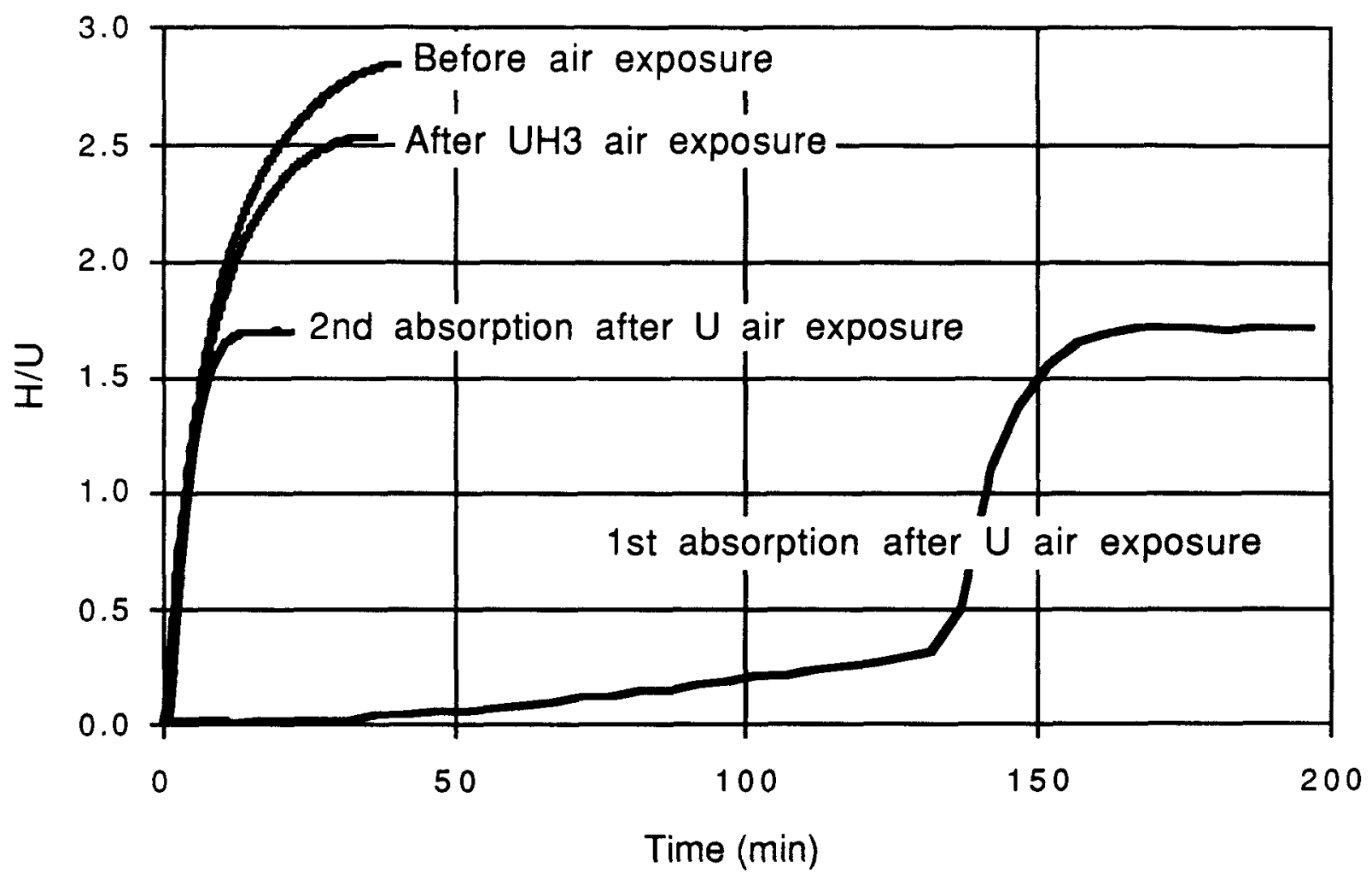

